\title{
18. Sámi placenames, power relations and representation ${ }^{1}$
}

\author{
Kaisa Rautio Helander \\ Sámi allaskuvla, Sámi University College, Norway
}

Language plays an important role in forming the social world and it is used to construct and shape social and political reality. According to Clark and Dear (1984: 84), "language is studded with signs, icons or symbols, which may carry meanings in excess of the simple word being used". Power relations are also institutionalised in language, at the same time as it functions as a means of social contact and communication. Language has the effect of including or excluding various groups and individuals according to their perception of the linguistically created "reality" (Clark and Dear 1984: 83-88). As Taylor (1985: 258) points out, "it is language which enables us to draw boundaries, to pick some things out in contrast to others. Thus through language we formulate things, and thus come to have an articulated view of the world".

Battiste and Henderson (2000: 74) write, concerning the significance of language in the ordering of the world, that "the people who have the power to decide what a thing will be called have the power to decide reality". It is precisely because placenames are a part of language, that they contribute to forming an image of the world, and thus also placenames can be used to influence a real perception of the world. The use of placenames, particularly in official contexts, is often connected to political aims (see e.g. Helander 2009a, 2013; Carter 2011; Berg and Kearns 2009; Kearns and Berg 2002; Clark and Kostanski 2012; Wilkinson, Marika and Williams 2009; Jordan 2009).

In this article, I shall examine how placenames can be used as part of a conscious effort to form representation. I shall pay special attention to what has happened to Indigenous Sámi placenames as the powers that be have, with the help of placenames, shaped representation to suit their own political aims. At the same time, this article also provides examples of what happens to traditional Sámi placenames in oral use when subjected to a written culture that is governed according to different criteria.

The noun Sápmi is used as a proper name, denoting the area, while the adjective, Sámi, is used in a more general sense, when referring to languages and placenames, thus, Sámi languages and Sámi placenames.

1 The original paper was published in North Sámi language in Sámi dieđalaš áigečála 1/2011, pp. 19-41 under the title, 'Sámi báikenamat, válddi relašuvnnat ja representašuvdna' (available from: http://site.uit.no/aigecala/ sami-diedalas-aigecala-1-2011-helander/). Minor revisions have been made for the English language version. 


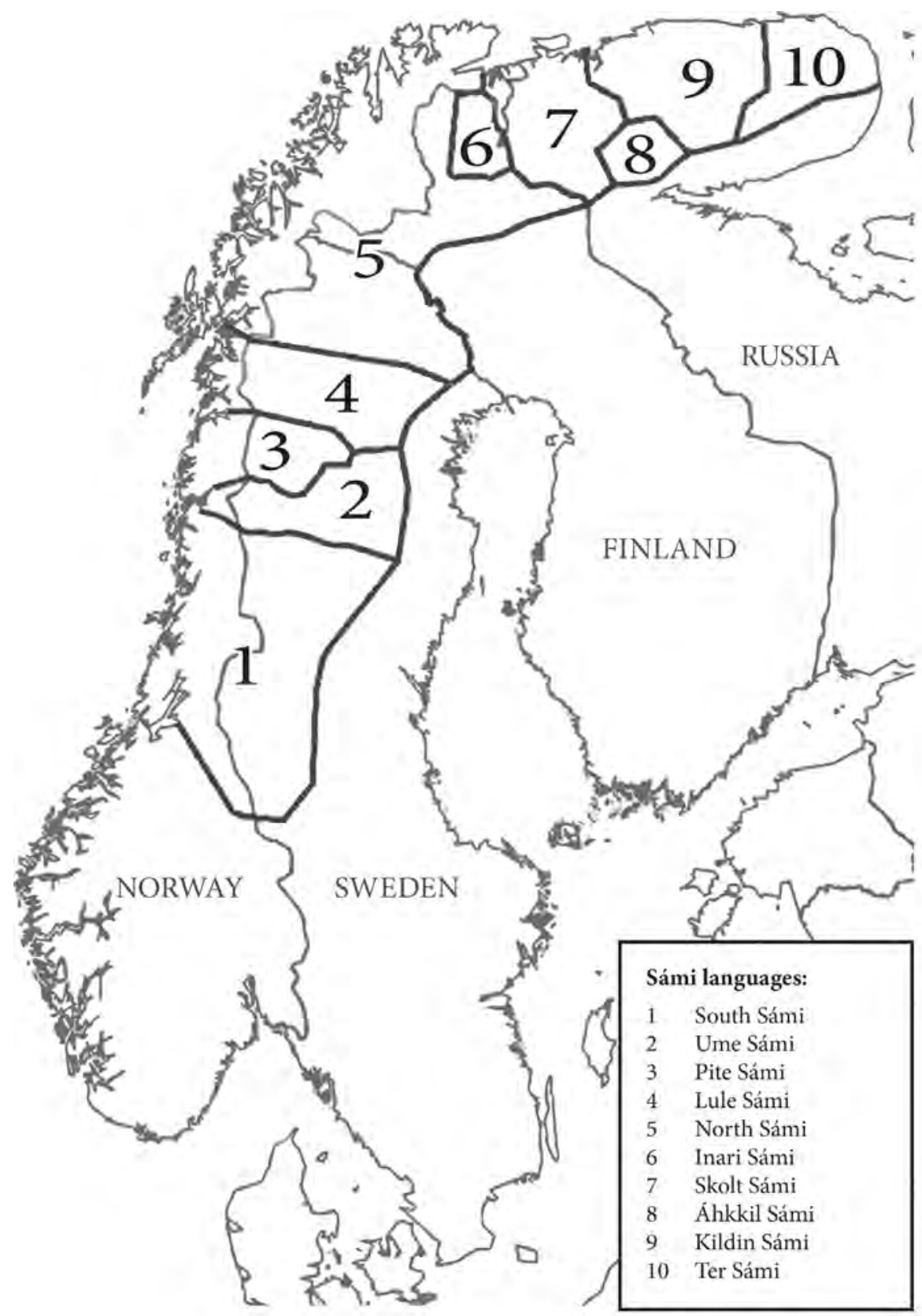

Map 1: The Sámi languages and the traditional settlement area called Sápmi.

Source: Map edition by Johan Isak Siri. 
Sápmi is the name of the area traditionally inhabited by the Sámi people and which lies in the Artic region of four nation states, Norway, Sweden, Finland and Russia (Map 1). The borders of these nation states were first drawn through the Sámi speaking area in the middle of the 18th century (see section 3 for further details). The Sámi languages are Indigenous languages in the Nordic countries as well as in Russia's Kola Peninsula. The Sámi languages do not have official status throughout the whole of the Sámi area, and have only recently started to acquire some of the language rights that are a matter of course for the majority languages in the Nordic countries. North Sámi has the strongest legal protection of all the Sámi languages. (Helander 2006; Aikio 2002; Sammallahti 1998.) In this article, examples of Sámi placenames are primarily North Sámi language names.

\section{What is representation?}

Representation is defined as "the cultural practices and forms by which human societies interpret and portray the world around them and present themselves to others" (Cloke, Crang and Goodwin 2005: 12). With a set of practices meanings are constructed and communicated. Hence, representations not only reflect reality, but they help to constitute reality. If one accepts that representation is an active, constitutive practice, then it follows that knowledge cannot be neutral or innocent of power relations (Johnston et al. 2000: 703-704). Representation is a consciously constructed image, formed to suit society's social and political purposes. "Representations of landscape are culturally determined, dependent on who is doing the 'seeing'." (Smith 2003: 72; see also Agnew 1998: 11-12; Helander 2009a).

As Paasi (1996a: 20) notes, "the signs and texts, particularly maps and cartography, which have been employed to illustrate and visualize this 'geography' - the space of geopolitics - have always been social and political instruments of power in the division of space" (see also Harley 2001). Hence, geography is also drawing and visualising the abstract and invisible boundaries of power which emerge from social practices and inherent human relations (Paasi 1996a: 20).

Power constructs are often examined in historical cartography, however, it is important to bear in mind that power relations are not just restricted to historical cartography, or to cartography at all for that matter. The structures of power relations can also clearly be seen in other historical and present-day activities such as, for instance in the administration of land-ownership, on road-signs and in other official naming practices (see e.g. Helander 2008, 2013; Kostanski and Clark 2009). Production of maps, administration of land-ownership, signposting of roads and other official use of nomenclature, all support one another and can thus be used to reinforce and maintain representation. 
Historically, it is mostly western, eurocentric representations that have governed and influenced the perception of the world. The question is namely, on whose terms, from whose perspective and for whose benefit representation is shaped and, furthermore, what kind of relationship is there between power structures and representations. Smith writes of the management of history, a factor that augments the power to control representation:

History is also about power. In fact history is mostly about power. It is the story of the powerful and how they became powerful, and then how they use their power to keep them in positions in which they can continue to dominate others. (Smith 2004 [1999]: 34)

Nevertheless, as Smith (2004 [1999]: 29-30) argues, "history is important for understanding the present and reclaiming history is a critical and essential aspect of decolonization." With respect to the official use of placenames, representation and the study, from a historical perspective, of how it continues and is maintained, reveals that representation is a construct that has been built up over a long period of time. A change in representation will often provoke opposition from precisely the majority population as the current placename discussion in Norway clearly demonstrates (a more detailed account of this in section 6) (see also e.g. Puzey 2009, 2011, 2012; Carter 2011; Matthews 2011; Kostanski 2009, 2011; Amery and Williams 2002). This kind of opposition is, therefore, also clearly an example of neo-colonial power structures. Analysing representation that has been shaped by placenames, it is also possible to examine why present-day Indigenous communities so often struggle to get their placenames recognised in official use. Demands to change long held representations are, therefore, part of Indigenous peoples' self-determination and toponymic decolonisation process. Hence the principal challenge of this process is the question of how to change long standing representations.

\section{The reinforcement through placenames of the European colonial representation}

Examination of colonial naming-processes and their results shows how placenames have been used to emphasise certain aspects of the real world and thus influence the form of representation. Harley (2001: 181) uses the term toponymic colonialism when referring to the renaming processes commonly employed in Indigenous regions, whereby placenames are given to localities that already traditionally bear names in the Indigenous language. This kind of renaming is linked most definitely to representation and, more precisely, to the formation of a certain type of representation. 
Toponymic colonialism is a term that also adequately describes other colonial naming practices in addition to renaming. There is also often discussion about which placenames are chosen or recognised for official use, which are silenced and which names of places are prioritised or emphasised in official use of toponyms. Another central question is who has the authority to decide which placenames are to be recognised in official use and in which language. (Cf. also Helander 2013.)

Since the end of the 15th century, European peoples have, as a result of colonialism, transferred their placename tradition to regions with Indigenous populations. It is possible to trace, since the time of Columbus, the ways in which European names have become established in colonised regions. Todorov describes the naming-methods employed by Cristóbal Colón or Christopher Columbus as follows:

At the beginning, we observe a kind of digram: the chronological order of the baptisms corresponds to the order of importance of the objects associated with these names. These will be, successively, God, the Virgin Mary, the King of Spain, the Queen, the Royal Prince. - - Later on, having more or less used up the religious and royal hierarchies, he resorts to a more traditional motivation. - - Columbus knows perfectly well that these islands [or places] already have names - - others' words interest him very little, however, and he seeks to rename places in terms of the rank they occupy in his discovery, to give them the right names; moreover nomination is equivalent to taking possession. (Todorov 1984 [1982]: 27-28)

Many kinds of renaming strategies have been used in all colonial regions, among others commemorative names, constructed according to various different motives, such as: places named after European seafarers Cook Island or Mount Cook, after captain James Cook or Tasmania and the Tasman Sea, after the Dutchman Abel Tasman. Even the name of entire continents such as America, is a commemorative name, the background to which being the name of the Florentine explorer Amerigo Vespucci. (MacKinnon 2009; Hodges 2007; Schwartz 2003; Berkhofer 1978).

When adapting names from Europe to the colonies, the transferrence of names was often employed. A common variation of this method was to add for instance the adjective new as an attribute to pre-existing European names. Very many names were constructed according to this model, such as from English, New England, New York, New Plymouth, New South Wales and also New Zealand, which had originally been given the Dutch name Nieuw Zeeland (Latin Nova Zeelandia), on the basis of which the present-day English form of the name was established as New Zealand. 
Through this method of naming, European naming tradition was transferred to a new context in such a way as to maintain, at one and the same time, a connection both to existing locations in the region of origin as well as to the naming models. This model supports eurocentric thinking, in which the world is divided, as a result of colonialism, into, from the European perspective, the Old World and the New World (see also Jacob 2006: 205).

This practice of naming is linked both to a nostalgia for the native land and to colonial projection. It has a function of a symmetrical axis that favours this doubling, the reflection of the Old World upon the New World. It represents a symbolic taking possession of a territory before the actual event. (Jacob 2006: 205.)

The role of colonial placenames has been to serve as a sort of linguistic stamp and symbol, something with which Europeans could mark places and regions and demonstrate ownership of the colonial regions. When, however, Indigenous peoples' placenames were silenced as a result of toponymic colonialism, it reinforced the perception of a terra nullius - as if the regions were not inhabited before the arrival of the Europeans. Thus, taking possession of these regions was legitimised through placenames (for greater detail see e.g. Miller 2008; Harley 2001; Byrnes 2001; Strack 2011; Black 1997; Blaut 1993). For this reason, placenames given by Europeans have been extremely significant as symbols, reinforcing ownership-rights to the regions of which they gradually took possession. In addition, representation is built up through the placenames, which, in turn, reinforce the colonisers' settlement history.

Characteristic of toponymic colonialism is the forming of representation, with which the perception of colonial ownership and domination is reinforced. According to Jacob (2006: 205), "the toponym is thus a signature, a claim of precedence and of symbolic ownership, analogous to the political and colonial mastery suggested by the name of the sovereign."

Naming a place anew is a widely documented act of political possession in settlement history. Equally, the taking away of a name is an act of dispossession. Silencing Indigenous toponymy "must be like being written out of history" (Harley 2001: 178-180; cf. also Ormeling 1983). Toponymic colonialism also has strong ties to the writing of history and to that representation, which is constantly being formed in the conscious writing of history. This is also referred to by the aforementioned Linda Tuhiwai Smith (2004 [1999]: 34) in her description of the management of history. The conscious writing of history, for its part, reinforces the perception of colonial peoples' ownership rights (see e.g. Miller 2008).

The history of European colonialism also demonstrates how maps have been used as a powerful means of visualisation, to establish and strengthen colonial representation (see e.g. Warhus 1997; Whitfield 1998; Edney 2009). Maps “were 
a medium in a wider colonial discourse for redescribing topography in the language of the dominant society" (Harley 2001: 179). "Thus maps are powerful images that helped to shape and reinforce the colonial view by authorising control and appropriating the land through its representation" (Smith 2003: 72). Through maps, and thus also through their choice of placenames, it is possible to control the world, since through these, information can be limited and shaped (cf. Turnbull 1993; Paasi 1996b; Häkli 2002).

"Although governments and those with political power had always used maps as a means of demonstrating and confirming the control they sought to exercise over space, it was not until the beginning of the nineteenth century that mapmaking became fully absorbed into the apparatus of the state." (Blacksell 2006: 31). State-sponsored topographical and toponymical surveys are key instruments for the expansion and consolidation of central government. They aid the internal colonisation of the nation-state as well as the incorporation of overseas territories. (Daniels 1998: 114; Godlewska 1995; Bassett 1994.) Thus in the 19th century, states started to control map-making in a more systematic way, in order to form maps in accordance with their own nationalistic objectives. Maps were extremely important in forming and consolidating nation-states' territorial representations. In the 19th century, maps started to become useful in the portrayal of national power, and with maps, it was easy to show, in a very tangible way, national territories. With the help of maps, an image of the nationstate was created in the mind of the people, and thus maps served the objectives of imagined communities (cf. Anderson 1991; also e.g. Kosonen 2000).

\section{Representation in Sápmi - examples of the use of placenames in Norway}

From here on, I shall examine the treatment of Sámi placenames, as an example of how placenames in the Nordic region have been used in shaping representation. In particular, I use the situation in Norway as an example of how, during the creation of nation-states, placenames have been a principal means of reinforcing a written narrative of national history, as well as territorial representation. Placenames on maps played an important role in visualising the nation-state's territorial image. The placenames of landed properties shaped the representation of the Norwegian people's settlement and settlement history. For this reason, during the period of nation building, the authoritites began to consciously control the use of placenames in Sámi areas (Helander 2008, 2009a).

It is, however, important to remember that the shaping of the representation of Sámi areas does not just begin during the process of nation-state building, but has a much longer history. As I have previously explained, the start of European 
colonialism, particularly in regions outside Europe, is reckoned from the end of the 1400s and the voyages of Columbus. The Sámi regions' contacts with the surrounding peoples go back way before the 15th century, and, as regards trading links and the taxation of Sámi in particular, have roots going back to prehistoric times. The most important literary evidence of the taxation of Sámi is the account given by Ottar to Alfred King of Wessex at the end of the 9th century (Hansen and Olsen 2004; see also Hansen 2011).

Though states' interest in Sápmi is over 1,000 years old, literary documents from the Sámi regions only exist from the end of the 16th century. Placenames are also mentioned in sources from that time, since they were used in administrative documents such as tax and court records, letters and other documents. The sources show in what ways the various different authorities, in their various different languages, have used placenames and recorded them in documents. Placenames have been documented in many languages, such as Danish, Norwegian, Swedish, Finnish and Russian, as the surrounding states had been competing for territory in the Sámi regions in the preceding centuries, before these regions were divided between the nation-states as territory, for the first time in the year 1751. Thus we can trace in Sápmi, the same competition for ownership of areas of land that we see in European colonialism. In the history of the Nordic countries, the terms private Sámi, common Sámi and common areas are used. These terms show how the surrounding peoples and governing states divided the Sámi regions among themselves as their own sphere of interest, and controlled Sámi ownership e.g. through taxation- and trading rights.

Placename use in Sámi regional sources does not give a true picture of Sámi name use as a part of oral traditon, since, for the most part, this is silenced in the sources. As Bergsland (1974: 1) writes, Sámi history has been written by others than the Sámi for others than the Sámi. This has also meant that Sámi placenames have been documented according to other criteria and requirements than those of the Sámi (see also Helander 2004a, 2008; Bergsland 1991; Hansen and Olsen 2004).

The fact that written sources contain few Sámi language placenames does not mean that those places have not had Sámi names. It means, rather, that the authorities managed to get by with the Scandinavian macrotoponyms of the main centres that already existed at the time. (Frette 1984: 69; Helander 2008: 65-66.)

It is significant, that placenames in historical sources were, for a long time, on the macro-level, so that the names of Sámi siidas (or tribes) and main areas and the biggest localities were mentioned. The placenames found in these written sources are macro-toponyms for those localities, to which outside society has given names on the basis of its own needs and requirements. These documents also show that other language naming in Sápmi was not always widely used at 
the outset of settlement history, but that it was rather used as administrativehistorical documentation, which demonstrates the interests the governing states or peoples had in the Sámi regions (Helander 2008: 148). The majority language use of nomenclature in historical documents has, however, over time, built up a false impression of settlement history. In Norway in particular, Norwegian etymological name-studies have also been used in explanations of settlement history that are used in the Sámi region in interpreting the settlement history of the Norwegian people (cf. Rygh 1924 etymological explanations; Helander 2008: 86-87). It is precisely because the sources lack systematic documentation about how the Sámi themselves have used placenames, that the silencing, in turn, has reinforced the false impression that a Sámi settlement history was also in fact lacking.

However, a detailed examination of Scandiavian placenames also reveals how naming and naming practices have often had Sámi language names both as their starting-point and model. Frette (1986) has explained the anger (-n) 'fiord' -names on Norway's northernmost coast as being Norwegian language names constructed on the basis of Sámi placenames. The locations' original Sámi names have been adapted to the Norwegian name-system, such as in North-Troms Sám. Gohppi 'round bay; inlet' + Nor. angen $>$ Koppangen and Sám. Coalbmi 'sound' + Nor. angen > Kjølmangen. What we have here, are examples of the transferrence model, in which Sámi names are the basis for the construction of Norwegian names, which are then, in this particular naming practice, adapted to the Norwegian-anger-name model.

On the other hand, many centuries of Norwegian administrative toponym use may also have had an effect on the use of original Sámi names, as shown by the example of the Norwegian Porsanger and Sámi Leavdnja. The Sámi name, Leavdnja was originally used as the name for the whole region. In addition, the loan-name Porsángu also became established, loaned from the Norwegian name, Porsanger. The use of this loan-name has had such an effect, that the placename Leavdnja has gradually aquired another use, and is therefore, in current Sámi, almost always used as the name of a town, and no longer exclusively as the name of the whole region (Helander 2008: 46-47).

In such cases where a Sámi name is recorded in historical sources, it is usually written according to other languages' antiquated orthographical principles, as shown by the name forms Polmak (in Sámi Buolbmát) and Karasjok (in Sámi Kárášjohka). Such written forms gradually became established, particularly as the names of towns or villages, more precisely in Norwegian-speaking name use.

The same type of processes have also occured with respect to other Indigenous peoples' placenames, as other language authorities have proceeded to write Indigenous names on the basis of their own languages. Gordon has written 
about a similar loan-process involved in the transfer of names from the oral language of the Iroquois tribe in North America to the written name-tradition of the colonial people:

Iroquois place-names, like their language, existed primarily in oral form. Whites recorded Iroquois place-names phonetically in their own written languages. When Indian place-names were needed in white documents concerning land grants, treaties, laws and settlements, they were usually recorded by a white law clerk. This procedure introduced Iroquois place-names into official white oral and written usage, thus also establishing them in white place-name landscape. (Gordon 1984: 222)

When Iroquois names were used in the colonial peoples' documents, it meant that the names became established in the placename landscapes of the white man, as Gordon describes the process. Kostanski and Clark (2009: 189) use the term Anglo-Indigenous to describe the type of Australian Indigenous placename that has been transferred to an English speaking context, in connection with cartographic work. Hence, this is the same type of name-loan process as in the Sámi regions, where Sámi placenames are used in written contexts, and thus become established in Norwegian. Suitable examples of this would be, among others, the names Alleknjarg, Sirma, Stallogargo, Sarves and Haldde, which are old orthographic forms of Sámi placenames, but which are used in these forms, particularly in a Norwegian context (see also Helander 2009b).

\section{Conscious renaming in Sámi regions intensifies in the 19th century}

The structures of European colonialism were tightened at the end of the 1800s, at the same time as the process of nation-state building was started (cf. Yazzie 2000: 39). It is worth noting, therefore, that by the time of the nation-state building process, the treatment of Indigenous peoples and minorities had been linked to many centuries of colonialism. The aim of the nation-state was to build a representation of a mono-lingual, mono-cultural society. The treatment of placenames therefore, also demonstrates similar methods of toponymic colonialism to those demonstrated in the naming processes of historical colonialism. The official use of Sámi placenames in the Nordic countries was also restricted, particularly from the 1800 s onwards, as part of the nation-building project. Prioritising and linguistic selection of placenames were practised as a powerful strategy, with which the nation-states could reinforce the perception of a 'We', in accordance with national ideological objectives. 
In Norway, the first piece of legislation concerning the Norwegianisation of Sámi placenames was implemented in 1876, when an amendment dealing with minority names was added to the Finnmark Land Purchasing Act (which had been revised in 1863) (Helander 2004b: 109). With this legislation, the use of Sámi placenames was regulated according to the aims of Norwegianisation policy. From the 1870s on, official use of placenames in Norway was closely controlled, in accordance with more strictly defined aims. Placenames in Sámi regions had been Norwegianised well before the amendment to the Land Purchasing Act, as explained in the previous section, but the Norwegianising of names had not, until that point, been regulated in such detail or so obviously controlled by central government authorities as it came to be from the 1870s onwards (Helander 2008, 2009a).

The authorities in Norway linked the Norwegianisation of Sámi placenames to sections in the Land Purchasing Act and to recommendations for map-making. As I have explained in the previous section, there had long been Norwegian placenames in the Sámi regions at the macro-toponymic level. In Scandinavian sources that describe the Sámi regions located in present-day Norway, the Norwegian names are, to begin with, mostly in coastal areas, however, Norwegian naming has gradually expanded, from the coast to the fiords and ultimately to the interior. This naming history is, therefore, very similar to the colonial naming process of the Europeans, as described in other regions. Regions were colonised first at the coast, as Cronon (2003: 19-20) describes in the case of New England in the colonisation of America, "for many years, the only New England known to Europe was near salt water" (see also Harley 2001: 169-195; Hodges 2007: 383-384).

As, among other things, the making of topographic maps was started in Norway, and the sale of land became more strictly regulated through the Land Acts of the 19th century, the authorities also found it necessary to extend Norwegian naming to include micro-toponyms, in particular, locations of Sámi settlement. From that time, a conscious Norwegianisation of Sámi placenames was set in motion, with the clear aim of forming a suitable representation for the nation of Norway. Two toponymic strategies were employed in this process: toponymic silence and toponymic subjugation (for more detail, see Helander 2008, 2009a).

Toponymic subjugation is a consciously employed hierarchy, in which the Indigenous placename is subjugated in relation to the majority language placename. In 1876, an amendment was added to Norway's Land Purchasing Act, which stated:

Landed property shall be given a Norwegian name, and any potential Sámi and Kvæn name shall be added in brackets. (Reg. $1876 \S 3$ f.) 
With this provision, a clear hierarchy was created, in which Sámi settlement names were subjugated in relation to Norwegian names. Toponymic subjugation was also emphasised in cartographic recommendations from the 1880s, particularly in cases where a place did not previously have any kind of name in Norwegian. According to the recommendations, the Sámi name was to be translated into Norwegian and the translated form was then be given priority as the correct name. The Sámi name was to be put in brackets (NGO 1886; Instr. 1895: 23).

Toponymic subjugation is a strategy in which places' original Sámi names are accepted in official use. With the hierarchy, however, the impression is created that the Norwegian names are the correct and proper names and that the Sámi names are just some kind of additional name. It is worth noting, that often, only the Sámi name was in oral use, and the Norwegian name was merely a constructed name, based on political decisions, yet it was still given priority. A feature of consciously constructed Norwegian placenames is that Sámi placenames serve as the starting-point or model for them, in that they are either translated or adapted from Sámi to Norwegian. It was often even the case that the local inhabitants had to translate the names for the cartographers. (Helander 2009b.)

The construction of placenames led to many types of manufactured Norwegian names, since the translation of placenames is, methodologically speaking, a difficult and sometimes even impossible process. (Helander 2008; cf. also e.g. Short 2009.) (The linguistic loan-methods of the Norwegianisation of placenames are analysed in greater detail in Helander 2007, 2008, 2009b.)

The clear aim of toponymic subjugation was to establish Norwegian names and to eliminate Sámi names. Sámi names were, nevertheless, needed as an aid until the use of the Norwegian names became properly established. The objective of toponymic subjugation was, therefore, similar to that of the Norwegianisation of the school: in the view of the authorities, the Sami language was only fit to serve as an aid until the time when it was rendered obsolete by Norwegian.

Another power-strategy with which the official use of Sámi placenames was to be controlled, and which has heavily influenced representation, is toponymic silence. According to this strategy, the Sámi placename was not officially recognised at all. Toponymic silence was used in Norway, both in selecting names for landed properties as well as in the making of topographic maps. The use of this strategy was decided in the year 1902, with a provision of the Land Purchasing Act:

"surveyed landed property is to be given a Norwegian name" (Ot.prp. 1901). 
In this way, the toponymic silencing of the Sámi names of settlements was used in conjunction with land ownership and the formation of a settlement-historical representation. This provision in the Act had a great effect, to the extent that the names of Sámi settlements have remained, almost excusively, in oral use and have not been recognised in any kind of written context such as land-registers, cadasters, maps or road-signs (see also Daniels 1998: 115).

The toponymic silencing of Sámi placenames was already a common strategy in historical sources. Thus the toponymic silence from the end of the 19th century was, by no means, a new method, but, rather, a continuation of a model that had long been employed in the Sami regions. What is, however, worth mentioning is that in the 19th century, the conscious construction of Norwegian placenames increased significantly, including at the micro-toponymic level. With the silencing of Sámi names and the priority given to Norwegian names, the Norwegian names were established in the kind of micro-level localities that had not previously had any oral tradition at all as regards parallel Norwegian names. (Helander 2008: 148-149; cf. also Helander 2004a: 75-77.)

\section{The effects on representation of toponymic subjugation and toponymic silence}

The examples from Table 1 show how toponymic subjugation and toponymic silence have been used against the official use of Sámi placenames. The table contains the names of Sámi settlements from the area around Girkonjárga in Mátta-Várjjat, in the easternmost part of the county of Finnmark in northern Norway. The names have been written as they were marked on three maps from the 1800s. The examples show that, on ethnographic maps from the years 1861 and 1888, Sámi placenames are marked, for the most part, in toponymic subjugation, i.e. they are written in brackets under the Norwegian name. When the topographic map ( $\leftleftarrows 5$ Neiden) was published in the year 1893, not one Sámi settlement name was recognised, and these names, in use in oral tradition, had been silenced in official use.

The examples from Table 1 show how toponymic subjugation is easily changed to toponymic silence. The examples also show that the silencing of Sámi settlement names gives the impression that, in the course of approximately 30 years, a language shift has occured, since the silencing of all the settlement names is easily interpreted as a silencing of Sámi settlement history and of the Sámi language. Hence, with the toponymic silencing of placenames, a representation is created that supports the perception of a Norwegian settlement area thus giving a false impression of both Sámi settlement history and of the state of the Sámi language. 
Indigenous and Minority Placenames

Table 1: From the toponymic subjugation to the toponymic silencing of Sámi settlement and hamlet names in the area around Girkonjárga in Mátta-Várjjat (according to Helander 2008: 153-154).

\begin{tabular}{|l|l|l|}
\hline $\begin{array}{l}\text { Friis (1861-1): } \\
\text { Ethnographic map }\end{array}$ & $\begin{array}{l}\text { Friis (1888-2): } \\
\text { Ethnographic map }\end{array}$ & $\begin{array}{l}\text { AE5 Neiden (1893): } \\
\text { Topographic map }\end{array}$ \\
\hline $\begin{array}{l}\text { Dimesholm } \\
\text { (Timberrovve) }\end{array}$ & $\begin{array}{l}\text { Dimesholm } \\
\text { Timberrovve }\end{array}$ & Dimesholmen \\
\hline $\begin{array}{l}\text { Braselv } \\
\text { (Guollevæijokka) }\end{array}$ & $\begin{array}{l}\text { Braselv } \\
\text { (Guolleveijokka) }\end{array}$ & Braselven \\
\hline $\begin{array}{l}\text { Storbugt } \\
\text { (Nirvagoppe) }\end{array}$ & $\begin{array}{l}\text { Storbugt } \\
\text { (Nirvagoppe) }\end{array}$ & Storbugten \\
\hline $\begin{array}{l}\text { Leervaagnæs } \\
\text { (Ruovvenjarga) }\end{array}$ & $\begin{array}{l}\text { Leervaagnæs } \\
\text { (Ruovvenjargga) }\end{array}$ & Steinskjærneset \\
\hline $\begin{array}{l}\text { Skogerönæs } \\
\text { (Salamgæčče) }\end{array}$ & $\begin{array}{l}\text { Skogerönæs } \\
\text { (Salamgæčče) }\end{array}$ & Skogeröneset \\
\hline $\begin{array}{l}\text { Höbugt } \\
\text { (Nuovisgoppe) }\end{array}$ & $\begin{array}{l}\text { Höbugt } \\
\text { (Nuovisgoppe) }\end{array}$ & Höibugten \\
\hline $\begin{array}{l}\text { Junkerelv } \\
\text { (Lonkesjokka) }\end{array}$ & $\begin{array}{l}\text { Junkerelv } \\
\text { (Lonkesjokka) }\end{array}$ & Lonkoselven \\
\hline $\begin{array}{l}\text { Buholm } \\
\text { (Čaigak) }\end{array}$ & $\begin{array}{l}\text { Buholm } \\
\text { (Čaigak) }\end{array}$ & Buholmen \\
\hline $\begin{array}{l}\text { (Oažželuokta) } \\
\text { Stonga }\end{array}$ & Staanga & Staanga \\
\hline $\begin{array}{l}\text { Piselvnes } \\
\text { (Akkalanjarg) }\end{array}$ & $\begin{array}{l}\text { Kirkenes } \\
\text { (Akkolagnjargga) }\end{array}$ & Kirkenes \\
\hline $\begin{array}{l}\text { Ropelv } \\
\text { (Jurrajokka) }\end{array}$ & $\begin{array}{l}\text { Ropelv } \\
\text { (Jurrajokka) }\end{array}$ & I Ropelven \\
\hline Guocagoppe & $\begin{array}{l}\text { Strømbugt } \\
\text { Guocagoppe }\end{array}$ & Strømbugten \\
\hline $\begin{array}{l}\text { Sandnæs } \\
\text { (Goadda) }\end{array}$ & $\begin{array}{l}\text { Sandnæs } \\
\text { (Goadda) }\end{array}$ & Sandnes \\
\hline
\end{tabular}

Source: Compiled from Friis (1861, 1888); Neiden (1893).

This representation is also reinforced by the series of books entitled Norske gaardnavne (Norwegian farm names), which contains the collected names of settlements from the end of the 19th century, arranged according to county (see e.g. Rygh 1924). In these books, the area from the counties of Trøndelag in the south to the county of Troms in the north, has no mention of Sámi settlement names, but only of official cadaster names. Thus, even this literary data maintains the toponymic silence with respect to Sámi settlement. In the series' section on Finnmark (Rygh 1924), mention is made of Sámi settlement names, but even in this section, the Norwegian names are, in most areas, indicated as the primary names and written in bolder lettering than the Sámi names. The way the book emphasises the Norwegian names while subjugating the Sámi names reinforces the representation, according to which, the Norwegian names 
are the correct names and the Sámi names just some sort of additional names. The lexical semantic etymology of the composite elements of the Norwegian names also supports the view that these Norwegian names were original. Such interpretations, however, do not take into consideration the loan processes that link these Norwegian names to the Sámi names in the surrounding area (Helander 2008: 90-95). This series of books still carries weight in Norwegian speaking circles and is, therefore, still reinforcing an old, established representation from the Norwegianisation period.

Both toponymic subjugation and silence are powerful strategies that have greatly influenced the way representation in Sami areas has been shaped over time through placenames. As regards land purchasing, the Norwegianisation of Sámi settlement names was completed in the year 1902 through a provision of the Land Act, for, since that time, settlement names were to be only in Norwegian. Characteristic for the name use in maps has, to this day, been that the Sámi names of settlement areas have been silenced. Thus, in maps, a two-way division appeared, with the subjugated use of Sami names in uninhabited areas and the exclusive use of Norwegian names in settled areas. Thus, topographic maps have also supported the representation, as if all areas of settlement were Norwegian speaking and inhabited by Norwegians, and Sámi life and culture were considered nomadism (Helander 2008; 2009a: 257-258).

The emphasis on naming in settlement areas, rather than uninhabited areas, has also been a contributory factor in building up the western world's characteristic dichotomy of civilised culture and untamed nature. Settled areas were areas of civilised culture and the priority given to Norwegian placenames in such areas supported this perception. According to the writing of history that occurred in Norway in the 19th century, fixed-dwelling, agrarian, Norwegian-speaking people were able to form history and have the right to own land. The Sami way of life, on the other hand, was defined as nomadism, which did not qualify for the right to own land. Thus a representation formed through placenames also reflects the history of Sámi rights (Helander 2008: 84-85; cf. also Agnew 1998: 36; Blaut 1993: 25; Miller 2008: 26-29).

The recognition of Indigenous placenames in official use divides similarly into two spheres in other Indigenous areas, with on the one hand, names of natural features and on the other, names of settlements. For example, in the state of New South Wales in Australia, a name-policy has been in force since 2001 which supports the use of dual placenames. It is now possible to have both the Aboriginal and European name in parallel official use. In practical terms, this means that Indigenous names can now be added to European names already in use (Geographical Names Board of New South Wales 2010: 1). It is significant, however, that in the recommendations for this bi-lingual or dual name use, there is one principle restriction: dual names may apply in the case 
of natural features (such as mountains, rivers, lakes and other features of the natural environment), but the names of suburbs, towns or streets must be in one language only (Geographical Names Board of New South Wales 2010: 1). This means that only the English names of towns and cities that have been in official use until now, will continue to be the official names of those towns and cities. This restriction is also, therefore, an example of how Indigenous names are not recognised as the names of inhabited or settled areas, but only as the names of natural features. Hence, even this regulation maintains the representation, according to which, aboriginals belong in nature or natural surroundings but not in urban environments.

\section{Maintenance of representation in Norwegian Sápmi and present-day linguistic landscape}

As road-building in Norway gradually expanded during the 20th century, village names also started appearing on road-signs. These made use of the same Norwegian placenames that had been documented in, among other records, land registers and various types of maps, such as Karlbotn, Nyborg, Furuflaten, Skardalen, Snubba, Kjøpsvik and Drag. It is only since 1990 and the Place Name Act (Lov 1990), that it has been possible to officially recognise the Sámi names of settlements and villages on an equal standing with the Norwegian names. Official recognition of Sámi names is part of a current decolonisation process, which means changes in power-constructs and equal prestige in the use of the Sámi names from an oral tradition as in the Norwegian placenames. Since the 1990s, therefore, many Sámi village names have been proposed for official use, as parallel names to the aforementioned Norwegian village names, Karlbotn $\sim$ Stuorravuonna, Nyborg $\sim$ Rovvejohka, Furuflaten $\sim$ Vuošvággi, Skardalen Skárfvággi, Snubba $\sim$ Duorga, Kjøpsvik Gásluokta and Drag $\sim A ́ j l u o k t a . ~ N o t$ one of these parallel Sámi village names has yet (2013) been introduced into official use, especially on road-signs.

Road-signs are a very visible part of linguistic landscape. According to Shohamy (2006: 110), "the presence (or absence) of language displays in the public space communicates a message, intentional or not, conscious or not, that affects, manipulates or imposes de facto language policy and practice". Roadsigns in Sámi regions that have names only in Norwegian are still representing the authorities' Norwegianisation policy and the views of the dominant or governing culture (cf. Ben-Rafael 2009: 49).

Road-signs are very powerful, since we see them a lot and thus their nameuse has an even greater effect on people's day-to-day use of language and their perception of the real world than maps. Thus linguistic landscape formed by 
placenames has also supported exactly the same mono-lingual Norwegian representation that has, through a conscious naming policy, been built up in Norway throughout the whole of the 20th century. The maintenance of a representation built up over a long period of time is a central element in the strategies employed by the powers that be. According to Ben-Rafael (2009: 40), it is still common practice for the power-culture, through its hegemony, to control linguistic landscape. The nation-state is a perfect example of this, where only the national language is used as the recognised language in linguistic landscape. "The more the power-relations principle plays a role in linguistic landscape structuration, the more this aspect might be the object of confrontations, or wars of words", as Ben-Rafael (2009: 47) also calls this type of confrontation. Public space and linguistic landscape can be an arena for ideological battles (Shohamy 2006: 110-111).

In Norway, changing the silence of settlement names has proved to be a difficult process. Proposed Sámi language village names have, since the 1990s, provoked various confrontations, media-discussion and, more recently, fierce opposition to Sámi placenames on social media (e.g. Helander 2006, 2013; Oskal 2003; Johnskareng 2008; NRK 2011; cf. also Dal Negro 2009). A characteristic feature of this opposition is its capacity to influence, in particular the view of the various local authorities. What this means in practice, is that the toponymic silencing of Sámi settlement names continues and official recognition, particularly of village names, is progressing only sporadically (Helander 2013).

According to Backhaus (2007: 5), "public signs are a specific type of semiotic sign in that they too stand for something other than themselves". The addition of Sámi village names to road-signs is interpreted and perceived as a symbol of Sámi rights. Sámi village names proposed for road-signs are regarded, therefore, as the visual sign of Sámi rights. The opposition, therefore, to the official use of Sámi town and village names is not just an opposition to road-signs, but to Sámi rights in general and thus also to linguistic and settlement historical rights (Helander 2013). The opposition to public use of Sámi village names in Norway, particularly on road-signs, also shows that official use of Sámi village names is perceived as a threat, to the whole mono-lingual, mono-cultural representation of settlement areas, which was consciously built up during the 20th century.

\section{Conclusion}

In this article, I have discussed how the use of placenames is often linked to political aims and how placenames are used to construct a representation. More particularly, I have shown, through the analysis of the use of Sámi placenames, how both toponymic silencing and toponymic subjugation have been employed 
as powerful strategies that have, with the help of placenames in Sámi areas, reinforced the aforementioned erroneous representation. A deeper study of placenames also shows how a division has been created between settlement names and the names of natural features in such a way that Sami settlement names are the most adversely affected by toponymic silencing. The methods of toponymic colonialism in Sámi areas are very similar to placename-constructed representations in other Indigenous regions, since it is especially through toponymic silencing that the official use of other Indigenous placenames is also, to a great extent, controlled and politicised.

According to Battiste (2000: xix), postcolonial societies do not exist. Rather, the colonial mentality and structures still exist in all societies and nations and the neocolonial tendencies that resist decolonisation in the contemporary world. As exemplified in this article, neocolonialism also includes toponymic neocolonialism, since societies retain the power-structures and methods of implementation with which the official use of Indigenous placenames is still controlled and resisted. Characteristic for toponymic neocolonialism is precisely the retention and maintenance of long-held representations. It is necessary to further research the methods and effects of toponymic colonialism and neocolonialism in order to find more robust methods to promote the process of toponymic decolonisation.

\section{References}

Agnew, J. 1998, Geopolitics: Re-visioning World Politics, Routledge, LondonNew York.

Aikio, A. 2002, 'The geographical and sociolinguistic situation', in Siiddastallan: From Lapp Communities to Modern Sámi Life, J. Pennanen and K. Näkkäläjärvi (eds), Publications of the Inari Sámi Museum nr 5, Siida Sámi Museum, Inari: 34-40.

Amery, R. and G. Y. Williams 2002, 'Reclaiming through renaming: the reinstatement of Kaurna toponyms in Adelaide and the Adelaide Plains', in The Land is a Map: Placenames of Indigenous Origin in Australia, L. Hercus, F. Hodges and J. Simpson (eds), Pandanus Books and Pacific Linguistics, Canberra: 255-276.

Anderson, B. 1991 [1983], Imagined Communities: Reflections on the Origin and Spread of Nationalism, Revised edition, Verso, London.

Backhaus, P. 2007, Linguistic Landscapes: A Comparative Study of Urban Multilingualism in Tokyo, Multilingual Matters 136, Multilingual Matters, Clevedon - Buffalo - Toronto. 
Bassett, T.J. 1994, 'Cartography and empire building in nineteenth-century West Africa', Geographical Review 84(4): 316-335.

Battiste, M. 2000, 'Introduction: unfolding the lessons of colonization', in Reclaiming Indigenous Voice and Vision, M. Battiste (ed.), UBC Press, Vancouver - Toronto: xvi-xxx.

Battiste, M. and J. Y. Henderson 2000, Protecting Indigenous Knowledge and Heritage: A Global Challenge, Purich Publishing Ltd, Saskatoon.

Ben-Rafael, E. 2009, 'A sociological approach to the study of linguistic landscapes', in Linguistic Landscapes: Expanding the Scenery, E. Shohamy and D. Gorter (eds), Routledge, New York - London: 40-69.

Berg, L. D. and R. A. Kearns 2009, 'Naming as norming: "Race", gender and the identity politics of naming places in Aotearoa/New Zealand', in Critical Toponymies: The Contested Politics of Place Naming, L. D. Berg and J. Vuolteenaho (eds), Ashgate, Surrey - Burlington: 19-51.

Bergsland, K. 1974, 'Synsvinkler i samisk historie', Norsk Historisk Tidsskrift 53: $1-36$.

- 1991, 'Stedsnavn som historisk kilde', in Sámi kulturmuittut. Samiske kulturminner. Báikenammačoaggima giehtagirji, H. R. Mathisen, Keviselie (ed.), Romsa: 61-66.

Berkhofer, R. F. Jr 1978, The White Man's Indian: Images of the American Indian from Columbus to the Present, Alfred A. Knopf, New York.

Black, J. 1997, Maps and History: Constructing Images of the Past, Yale University Press, New Haven - London.

Blacksell, M. 2006, Political Geography. Routledge Contemporary Human Geography Series, Routledge, London - New York.

Blaut, J.M. 1993, The Colonizer's Model of the World: Geographical Diffusionism and Eurocentric History, The Guilford Press, New York - London.

Byrnes, G. 2001, Boundary Markers: Land Surveying and the Colonisation of New Zealand, Bridget Williams Books, Wellington.

Carter, L. 2011, 'The Big “ $\mathrm{H}^{\prime}$ : naming and claiming landscapes', in Making our Place: Exploring Land-use Tensions in Aotearoa New Zealand, J. Ruru, J. Stephenson and M. Abbott (eds), Otago University Press, Dunedin: 57-69, 220-222. 
Clark, G. L. and M. Dear 1984, State Apparatus: Structures and Language of Legitimacy, Allen \& Unwin, Boston.

Clark, I. and L. Kostanski 2012, 'Reintroducing Indigenous place names lessons from Gariwerd, Victoria, Australia, or, How to address toponymic dispossession in ways that celebrate cultural diversity and inclusiveness', in Proceedings of the 22nd International Congress of Onomastic Sciences, Section 5 Geographical Names, Edizioni, Pisa: 517-532.

Cloke, P., P. Crang and M. Goodwin 2005, Introducing Human Geographies, Second edition, Hodder Arnold, Oxon.

Cronon, W. 2003 [1983], Changes in the Land: Indians, Colonists, and the Ecology of New England, Hill and Wang, New York.

Dal Negro, S. 2009, 'Local policy modeling the linguistic landscape', in Linguistic Landscapes: Expanding the Scenery, Elana Shohamy and Durk Gorter (eds), Routledge, New York - London: 206-218.

Daniels, S. 1998, 'Mapping national identities: the culture of cartography, with particular reference to the Ordnance Survey', in Imagining Nations, York Studies in Cultural History, G. Cubitt (ed.), Manchester University Press, Manchester - New York: 112-131.

Geographical Names Board of New South Wales 2010, 'Dual naming - Supporting cultural recognition', Land and Property Management Authority, Sydney. Available from: http://www.gnb.nsw.gov.au/_data/assets/pdf_file/0004/58837/ P1021001_DualNaming.pdf (accessed 28 March 2011).

Edney, M. H. 2009, 'The irony of imperial mapping', in The Imperial Map: Carthography and the Mastery of Empire, J. R. Akerman (ed.), The University of Chicago Press, Chicago - London: 11-45.

Frette, T. 1984, 'Samiske og finske navn i eldre skriftlige kilder', in Den 3. nasjonale konferansen i namnegransking, B. Helleland (ed.), Universitetet i Oslo, Oslo: 69-73.

— 1986, 'Noen synspunkter på -anger (-angen)', in Årsmelding 1985, Institutt for namnegransking (Norsk stadnamnarkiv), Universitetet i Oslo, Oslo: 66-79.

Godlewska, A. 1995, 'Map, text and image: the mentality of enlightened conquerors: a new look at the Description de l'Egypte', Transactions of the Institute of British Geographers, New series, 20(1): 5-28.

Gordon, J. J. 1984, 'Onondaga Iroquois place-names: an approach to historical and contemporary Indian landscape perception', Names 32(3): 218-233. 
Hansen, L. I. 2011, 'Norwegian, Swedish and Russian "tax lands" in the North', in Taxes, Tributes and Tributary Lands in the Making of the Scandinavian Kingdoms in the Middle Ages, Trondheim Studies in History, S. Imsen (ed.), Tapir Academic Press, Trondheim: 295-330.

Hansen, L. I. and B. Olsen 2004, Samenes historie fram til 1750, Cappelen Akademisk Forlag, Oslo.

Harley J.B. 2001, The New Nature of Maps: Essays in the History of Cartography, Paul Laxton (ed.), The Johns Hopkins University Press, Baltimore - London.

Helander, K. R. 2004a, 'Muhtin fuomášumit báikenamaid njálmmálaš ja čálalaš anus Norgga beale davimus Sámis', in Samiske landskapsstudier, L. M. Andreassen (ed.), Dieđut 5, 2004, Sámi Instituhtta, Guovdageaidnu: 72-86.

- 2004b, 'Treatment of Saami settlement names in Finnmark in official Norwegian place name policy', in Landscape, Law and Customary Rights, M. Jones and A. Schanche (eds), Dieđut 3, 2004 2nd ed., Sámi Instituhtta Nordic Sámi Institute, Guovdageaidnu: 102-121.

- 2006, 'The legalization of Saami place names in Norway', in Proceedings of the International Conference on Minority Names / Indigenous Names and Multilingual Areas, K. Gildemacher, F. Ormeling and A. Versloot (eds), GeoNames 2005, Utrecht University, Utrecht: 52-58.

— 2007, 'Sámi báikenamaid dáruiduhttin uniovdnaáigge ja dárogiela namaid lonenvuogit', in Sámit, sánit, sátnehámit. Riepmočála Pekka Sammallahtii miessemánu 21. beaivve 2007, J. Ylikoski and A. Aikio (eds), SuomalaisUgrilaisen Seuran Toimituksia 253, Suomalais-Ugrilainen Seura, Helsinki: 137-159.

- 2008, Namat dan nammii. Sámi báikenamaid dáruiduhttin Várjjaga guovllus Norgga uniovdnaáiggi loahpas, Dieđut 1, 2008, Sámi allaskuvla, Guovdageaidnu.

- 2009a, 'Toponymic silence and Sámi place names during the growth of the Norwegian nation state', in Critical Toponymies: The Contested Politics of Place Naming, L. D. Berg and J. Vuolteenaho (eds), Ashgate, Surrey Burlington: 253-266.

- 2009b, 'Renaming Indigenous toponymy in official use in the light of contact onomastic theories', in Proceedings of the 23nd International Congress of Onomastic Sciences, York University, Toronto: 492-500. 
Indigenous and Minority Placenames

— 2013, 'The power of administration in the official recognition of Indigenous place names in the Nordic countries', in Names: People, Places, Perceptions and Power, Multilingual Matters. Forthcoming.

Hodges, F. 2007, 'Language planning and placenaming in Australia', Current Issues in Language Planning 8(3): 383-403.

Häkli, J. 2002, 'Mapping the historical sense of Finland', Fennia 180(1-2): 75-81.

Instr. 1895, Instruks for detaljemåling. Norges geografiske opmåling. Kristiania, Kart-samlingen, Statens kartverk, Hønefoss.

Jacob, C. 2006, The Sovereign Map: Theorethical Approaches in Cartography throughout History, The University of Chicago Press, Chicago - London.

Johnskareng, Á. 2008, 'Viđat rasisttalaš reivve ožžon', Ávvir 1 April: 4-5.

Johnston, R.J., D. Gregory, G. Pratt and M. Watts (eds) 2000, The Dictionary of Human Geography, Fourth edition, Blackwell Publishing, Malden - Oxford - Victoria.

Jordan, P. 2009, 'Place names as ingredients of space-related identity', Wiener Schriften zur Geographie und Kartographie 18: 33-39.

Kearns, R. A. and L. D. Berg 2002, 'Proclaiming place: towards a geography of place name pronunciation', Social \& Cultural Geography 3(3): 283-302.

Kosonen, K. 2000, Karttaja kansakunta. Suomalainen lehdistökartografia sortovuosien protesteista Suur-Suomen kuviin 1899-1942, Suomalaisen Kirjallisuuden Seuran Toimituksia 793, Suomalaisen Kirjallisuuden Seura, Helsinki.

Kostanski, L. 2009, 'Toponymic books and the representation of Indigenous identities', in Aboriginal Placenames: Naming and Re-naming the Australian Landscape, Harold Koch and Luise Hercus (eds), Aboriginal History Monograph 19, ANU E Press and Aboriginal History Incorporated, Canberra: 175-187.

Kostanski, L. 2011, 'Signs of the times: changing names and cultural values in Australia', Onoma 46: 251-274.

Konstanski, L. and Ian D. Clark 2009, 'Reviving old Indigenous names for new purposes', in Aboriginal Placenames: Naming and Re-naming the Australian Landscape, H. Koch and L. Hercus (eds), Aboriginal History Monograph 19, ANU E Press and Aboriginal History Incorporated, Canberra: 189-206.

Lov 1990, Lov 18. mai 1990 nr. 11 om stadnamn. Available from: http://www. lovdata.no/cgi-wift/wiftldles?doc=/app/gratis/www/docroot/all/nl-19900518011.html\&emne $=$ STADNAMNLOV $\& \&$ (accessed 19 December 2012). 
Matthews, P. W. 2011, 'Wanganui and Whanganui: a clash of identities', Onoma 46: 167-208.

McKinnon, M. 2009, Place Names: Te Ara - the Encyclopedia of New Zealand. Available from: http://www.TeAra.govt.nz/en/place-names (accessed 27 November 2009).

Miller, R. J. 2008, Native America, Discovered and Conquered: Thomas Jefferson, Lewis and Clark, and Manifest Destiny, University of Nebraska Press, Lincoln - London.

NGO 1886, Brev fra Norges Geografiske Opmaaling 23.12.1886 til Den Kongelige Norske Regjerings Forsvarsdepartements arméafdeling, Hovedarkivet, Statens kartverk, Hønefoss.

NRK 2011, Samiske skilt provoserer. Available from: http://www.nrk.no/ nyheter/distrikt/nordland/1.7495194 (accessed 1 April 2011).

Ormeling, F. J. 1983, Minority Toponyms on Maps: The Rendering of Linguistic Minority Toponyms on Topographic Maps of Western Europe, Elinkwijk Bv, Utrecht.

Oskal, N. 2003, 'Samisk offentlighet og demokrati på norsk', in Samer, makt og demokrati. Sametinget og den nye samiske offentligheten, B. Bjerkli and P. Selle (eds), Gyldendal, Oslo: 318-337.

Ot.prp. 1901, Ot.prp. nr. 20 (1901-1902), Angaaende udfardigelse af en lov om afhondelse af statens jord og grund i Finmarkens amts landdistrikt, Den norske regjerings underdanigste indstilling af 13de mars 1902, som ved kongelig resolution af 15 de mars $\mathrm{s}$. a. naadigst er bifaldt.

Paasi, A. 1996a, Territories, Boundaries and Consciousness: The Changing Geographies of the Finninh-Russian Border, Belhaven Studies in Political Geography, John Whiles \& Sons, New York.

- 1996b, 'Inclusion, exclusion and territorial identities', Nordisk Samhällsgeografisk Tidsskrift 23: 3-17.

Puzey, G. 2009, 'Opportunity or threat? The role of minority toponyms in the linguistic landscape', in Proceedings of the 23nd International Congress of Onomastic Sciences, York University, Toronto: 821-827.

- 2011, 'New research directions in toponomastics and linguistic landscapes', Onoma 46: 211-226.

- 2012, 'Two-way traffic: how linguistic landscapes reflect and influence the politics of language', in Minority Languages in the Linguistic Landscape, D. Gorter, H. F. Marten and L. Van Mensel (eds), Palgrave Macmillan, Basingstoke: 127-147. 
Indigenous and Minority Placenames

Regl. 1876, Reglement angaaende Fremgangsmaaden ved Afhondelse eller Bortforpagtning af Statens Jord og andre den tilhørende Herligheder $i$ Finmarkens Amts Landdistrikt i Henhold til Lov af 22de Juni 1863. Givet ved Kongelig Resolution af 6te Mai 1876, Kristiania.

Rygh, O. 1924, Norske gaardnavne. Navne paa matrikulerede jordeiendomme $i$ Finmarkens Amt, Udgivne med tilføiede forklaringer af J. Qvigstad og Magnus Olsen, Attende bind, W.C. Fabritius \& Sønner, Kristiania.

Sammallahti, P. 1998, The Saami Languages: An Introduction, Davvi Girji, Kárášjohka.

Schwartz, S. I. 2003, The Mismapping of America, The University of Rochester Press, Rochester - Woodbridge.

Shohamy, E. 2006, Language Policy: Hidden Agendas and New Approaches, Routledge, London.

Short, J. R. 2009, Cartographic Encounters: Indigenous Peoples and the Exploration of the New World, Reaction Books, London.

Smith, A. 2003, 'Landscape representation: place and identity in nineteenthcentury Ordnance Survey maps of Ireland', in Landscape, Memory and History: Anthropological Perspectives, P. J. Steward and A. Strathern (eds), Pluto Press, London - Sterling - Virginia: 71-88.

Smith, L. T. 2004 [1999], Decolonizing Methodologies: Research and Indigenous Peoples, Zed Books, London.

Strack, M. 2011, 'Bounding the land: cadastral framework on the Taieri', in Making our Place: Exploring Land-use Tensions in Aotearoa New Zealand, J. Ruru, J. Stephenson and M. Abbott (eds), Otago University Press, Dunedin: 101-114, 225-227.

Taylor, C. 1985, Human Agency and Language, Philosophical papers 1, Cambridge University Press, Cambridge.

Todorov, T. 1984 [1982], The Conquest of America, Harper Perennial, New York.

Turnbull, D. 1993 [1989], Maps are Territories: Science is an Atlas, A porfolio of exhibits, The University of Chicago Press, Victoria.

Warhus, M. 1997, Another America: Native American Maps and the History of Our Land, St Martin's Press, New York.

Whitfield, P. 1998, New Found Lands: Maps in the History of Exploration, Routledge, New York. 
Wilkinson, M., Dr R. Marika and N. M. Williams 2009, 'This place already has a name', in Aboriginal Placenames: Naming and Re-naming the Australian Landscape, H. Koch and L. Hercus (eds), Aboriginal History Monograph 19, ANU E Press and Aboriginal History Incorporated, Canberra: 403-462.

Yazzie, R. 2000, 'Indigenous Peoples and Postcolonial Colonialism', in Reclaiming Indigenous Voice and Vision, M. Battiste (ed.), UBC Press, Vancouver Toronto: 39-49. 
This text taken from Indigenous and Minority Placenames: Australian and International Perspectives, Edited by Ian D. Clark, Luise Hercus and Laura Kostanski, published 2014 by ANU Press, The Australian National University, Canberra, Australia. 